\title{
Form and Substance in Critical Legal Studies
}

\author{
J. Paul Oetken
}

In picking a form through which to achieve some goal, we are almost always making a statement that is independent or at least distinguishable from the statement we make in choosing the goal itself.

Duncan Kennedy ${ }^{1}$

Critical Legal Studies (CLS) presents a fundamental challenge to the legal system. CLS scholars try to establish the illegitimacy of the legal order by debunking law's pretensions to determinacy, neutrality, and objectivity. The movement ${ }^{2}$ is concerned with how people think and talk about law, not only as reflected in cases and statutes, but also in law school classrooms, in law journals, and in everyday life.

In an early and influential CLS article, Form and Substance in Private Law Adjudication, ${ }^{3}$ Duncan Kennedy examines the form and the substance of contract law, arguing that they are related and that the "opposed rhetorical modes" characteristic of both levels "reflect a deeper level of contradiction" in the liberal world vision. ${ }^{4}$ In particular, he argues that the contradictory rhetorics of rules and standards are tied to contradictory substantive commitments to individualism and altruism. This Note adopts Kennedy's methodology in that article, examining the form and substance of critical legal scholarship and identifying underlying contradictions ${ }^{5}$ in the CLS vision. It represents an

1. Kennedy, Form and Substance in Private Law Adjudication, 89 HARV. L. REV. 1685, 1710 (1976).

2. The use of the term "movement" is not meant to suggest that those associated with CLS necessarily agree in all their arguments. Within CLS there is a variety of worldviews and methodological approaches. See M. Kelman, A GUIDE to CrITCAL Legal StUdIEs 2 (1987); Hutchinson \& Monahan, Law, Politics, and the Critical Legal Scholars: The Unfolding Drama of American Legal Thought, 36 STAN. L. REV. 199, 219-27 (1984). It is widely accepted both within and outside CLS, however, that its scholars share sufficient themes, arguments, and approaches "to permit intelligent discussion of the movement as a whole." Johnson, Do You Sincerely Want to Be Radical?, 36 STAN. L. REV. 247, 249 (1984); see also Hutchinson, Introduction to CRITICAL LEGAL STUDIES 3 (A. Hutchinson ed. 1989) (describing common elements in CLS work); Tushnet, Critical Legal Studies: A Political History, 100 Y ALE L.J. 1515, 1518 n.16 (1991) ("[W]e share far more in our common opposition to a system of illegitimate hierarchy than we disagree among ourselves.").

3. Kennedy, supra note 1 .

4. Id. at 1685 .

5. The sense of "contradiction" used in this Note is that employed in Kennedy's article (and in CLS work generally), meaning simultaneous commitment to opposing discourses, values, or dichotomies. It should be distinguished from the stricter, technical meaning of the word in deductive logic as the conjunction of two inconsistent and exhaustive propositions (of the form $P \&$ not-P). See S. WOLFRAM, PHLOSOPHICAL 
example of internal critique - that is, it uses the methodologies and materials of CLS to analyze CLS itself.

This Note also draws on a growing literature that examines rhetoric in legal discourse. ${ }^{6}$ Its starting point is the proposition, common to both the CLS movement and the law-and-literature movement, that form and rhetoric are inherently connected to substance. ${ }^{7}$ This Note considers the rhetoric of critical legal scholarship and argues that CLS scholarship reflects contradictory rhetorical commitments, betraying a fundamentally confused substantive vision. The scholarship of $\mathrm{CLS}^{8}$ looks and sounds radical, but it fails to deliver on its promise of a coherent radical vision. Its form-in particular, its rhetoric-is related to its substance in important ways which demonstrate this incoherence. This Note identifies contradictory rhetorical commitments in CLS scholarship and the similarly contradictory epistemological, moral, social, and methodological commitments that they imply. The analysis reveals that CLS offers a fundamentally unstable vision. Ironically, the Critical Legal Studies movement ultimately fails to rise above the contradictory visions of life for which it faults liberalism.

Part I of this Note provides background by summarizing the key elements that make up the CLS critique of liberal theory. Part II identifies and analyzes six dichotomies-conflicting rhetorical tendencies in CLS scholarship corresponding to contradictory substantive commitments: inclusion versus exclusion; subjectivism versus structuralism; indeterminacy versus determinacy; humanism versus transcendentalism; particularity versus abstraction; and the radical versus the mainstream. Part $\mathrm{MI}$ discusses the relation between form and substance and the significance of contradictory commitments in critical legal scholarship.

\section{THE CLS CRITIQUe}

Before exploring the rhetoric of CLS scholarship, it will be helpful to provide some background on the CLS project. This Part briefly explains some

LOGIC 177-81 (1989).

6. See, e.g., J.B. WHITE, HeRACLES' Bow: EsSAYS ON THE RHETORIC AND POETICS OF THE LAW (1985); J.B. WHITE, WHEN WORDS LOSE THEIR MEANING (1984); Balkin, The Rhetoric of Responsibility, 76 VA. L. REV. 197 (1990); Frug, Argument As Character, 40 STAN. L. REV. 869 (1988); Wetlaufer, Rhetoric and Its Denial in Legal Discourse, 76 VA. L. REV. 1545 (1990).

7. For examples from the CLS movement, see Frug, supra note 6, at 872-75; Hutchinson, From Cultural Construction to Historical Deconstruction (Book Review), 94 YALE L.J. 209, 237 (1984); Kennedy, supra note 1 , at $1710,1712$.

Within the law-and-literature movement, James Boyd White notes that "to ask of this apparently nonliterary discourse questions about tone, character, form, and structure that are drawn from the reading of literature, may do much to expose what is otherwise hard to see about the nature of legal thought and expression . . . ." White, What Can a Lawyer Learn From Literature? (Book Review), 102 HARV. L. REV. 2014, 2032 n.51 (1989). For background on the contemporary varieties of law-and-literature scholarship, see Ayer, The Very Idea of "Law and Literature" (Book Review), 85 MICH. L. REV. 895 (1987).

8. For the purposes of this Note, critical legal scholarship is defined by the criterion of self-identification: it includes all and only scholarship that explicitly indicates an association with CLS or that is by authors who identify the corpus of their work as critical legal scholarship. 
central, interrelated elements in the CLS critique of liberal theory. ${ }^{9}$ Critical legal scholars attack the liberal legal order ${ }^{10}$ by focusing on the phenomena of formalism, determinacy, contradiction, objectivity, and neutrality.

\section{A. Formalism and Determinacy}

A central strain of the CLS critique of law is an attack on formalism - "the idea that there is an autonomous and neutral mode of 'legal' reasoning and rationality through which legal specialists apply doctrine in concrete cases to reach results that are independent of the specialists' ethical ideals and political purposes." it applies rules according to a rational, necessary, and objective method. ${ }^{12}$

Instead, CLS argues, law is indeterminate: legal rules and arguments fail to compel or justify definite answers in legal disputes. ${ }^{13}$ CLS advances several sophisticated arguments in support of the indeterminacy thesis. An internal critique takes the rules and arguments making up orthodox legal doctrine as premises and shows them to be inconsistent, incomplete, and ambiguous-and therefore indeterminate. ${ }^{14}$ An external critique, in contrast, stands outside the conventions of ordinary legal analysis and establishes indeterminacy by appealing to language, philosophy, or history. For example, CLS has used modern linguistic theory and deconstructive techniques to show that the nature of language renders law indeterminate, ${ }^{15}$ and has also focused on the role of social forces and power relations as the actual determinants of legal outcomes. ${ }^{16}$

9. In this Note, as in CLS literature, the terms "liberal" and "liberalism" are used in their classical sense rather than their modern political sense, thus encompassing all mainstream thinkers in the tradition of political theory exemplified by Locke, Bentham, Kant, Mill, and Rawls. In this sense, not only are Bruce Ackerman, Ronald Dworkin, and Mario Cuomo liberals, but Richard Posner, Robert Nozick, and George Bush are as well.

10. CLS scholars often use the terms "law," "legal order," and "legal system" interchangeably to denote the legal order, understood as including both the legal system and legal theory. Following them, this Note treats these terms as essentially synonymous. (1984).

11. Trubek, Where the Action Is: Critical Legal Studies and Empiricism, 36 STAN. L. REv. 575, 578

12. Kairys, Introduction to THE POLITICS OF LAW: A PROGRESSIVE CRITQUE 3 (D. Kairys ed. 1982).

13. Singer, The Player and the Cards: Nihilism and Legal Theory, 94 YALE L.J. 1, 11, 20 (1984).

14. See id. at 10-14.

15. See, e.g., Boyle, The Politics of Reason: Critical Legal Theory and Local Social Thought, $133 \mathrm{U}$. PA. L. REV. 685 (1985); Dalton, An Essay in the Deconstruction of Contract Doctrine, 94 YALE L.J. 997 (1985); Frug, The Ideology of Bureaucracy in American Law, 97 HARV. L. REV. 1276 (1984); Heller, Structuralism and Critique, 36 STAN. L. REV. 127 (1984); Tushnet, A Note on the Revival of Textualism in Constitutional Law, 58 S. CAL. L. REV. 683 (1985).

16. See, e.g., M. HORWTI, THE TRANSFORMATION OF AMERICAN LAW, 1780-1860 (1977); Gordon, Critical Legal Histories, 36 STAN. L. REV. 57 (1984); Kennedy, Toward an Historical Understanding of Legal Consciousness: The Case of Classical Legal Thought in America, 1850-1940, 3 RES. L. \& SOC. 3 (1980). 


\section{B. Contradiction}

Another central theme found in CLS literature is that the liberal legal order rests on contradictory visions of human nature. Duncan Kennedy has identified a "fundamental contradiction" in social relations between individual autonomy and communal force, between freedom and security. ${ }^{17}$ CLS scholars have identified several parallel "central contradictions" embedded in the fabric of liberal thought: free will versus determinism; ${ }^{18}$ the public versus the private spheres; ${ }^{19}$ subjectivity versus objectivity; ${ }^{20}$ individualism versus altruism; $;{ }^{21}$ and rules versus standards. ${ }^{22}$ These contradictions provide additional evidence of the legal order's indeterminacy and incoherence. But at the same time, CLS argues, the legal system (unconsciously) privileges one pole of each dichotomy, presumptively making it govern. What results is a legal order that is not neutral, but "remarkably right-wing," ${ }^{23}$ hierarchical, and morally objectionable. ${ }^{24}$

\section{Objectivity and Neutrality}

The CLS critique also rejects the legal system's pretensions to objectivity-the idea that there are rational, necessary criteria for answering legal questions. ${ }^{25}$ Instead, it argues that the formalistic, rational-sounding discourse of law actually contributes to mystification, false consciousness, and reification: "[L]egal discourse paints an idealized fantasy of order" and "cement[s] this feeling, at once despairing and complacent, that things must be the way they are and that major changes could only make them worse."26 For CLS scholars, this debunking of the myth of law's neutrality means that, at every level, legal decisions involve value and policy choices. ${ }^{27}$ Law serves as "an instrument of class domination . . . act[ing] to reproduce or to try to change people's social reality." ${ }^{28}$ In a very real sense, according to CLS, law is politics, all the way down. ${ }^{29}$

17. Kennedy, The Structure of Blackstone's Commentaries, 28 Buffalo L. REv. 209, 211-13 (1979).

18. M. KELMAN, supra note 2, at 86-113.

19. Gordon, supra note 16 , at 109-13.

20. M. KELMAN, supra note 2 , at 64-85.

21. Kennedy, supra note 1 , at 1685 .

22. Id.; M. KELMAN, supra note 2, at 15-63.

23. M. KeLMAN, supra note 2 , at 4 .

24. Kennedy, supra note 1 , at 1685 .

25. Singer, supra note 13 , at $25-39$.

26. Gordon, Unfreezing Legal Reality: Critical Approaches to Law, 15 FLA. ST. U.L. REV. 195, 198 (1987).

27. Kairys, supra note 12 , at 2 .

28. Gordon, supra note 16, at 94-95.

29. Tushnet, supra note 2 , at 1539. 


\section{The Rhetoric of CRitical Legal Studies}

The scholarship of the Critical Legal Studies movement demands that the reader pay attention not only to substance, but also to form-in particular, to rhetoric. ${ }^{30}$ A primary concern of CLS is to demonstrate how language and other formal structures are used in subtle, unconscious ways to channel our thought into dominant patterns, to mystify us. The way we talk about law is crucial to what law in our society is; our choices of words, connotations, images, and tone are coded with meanings and commitments. But if this is correct, then it is also important to ask what is encoded in the way CLS scholars talk about law. What is the connection between the distinctive rhetoric of CLS scholarship and its substantive vision? This Part examines that relation in an effort to bring together form and substance in CLS and tease out a picture of the fundamental CLS vision of law and its place in society.

The picture that emerges through the identification of rhetorical "commitments" and associated "contradictions" may seem, in a sense, somewhat stylized or artificial. The world of CLS is, of course, richer and more complex than it can be portrayed here. But CLS itself teaches that arguments and commitments are hidden within the seemingly neutral domain of form and rhetoric, and that these arguments and commitments can reveal deep contradictions. ${ }^{31}$ As an internal critique, this Note simply takes seriously the methods privileged by CLS and uses them to show that CLS's own rhetoric undermines itself.

It may be helpful to distinguish between two types of contradictions in CLS scholarship: those within the writing of a single author, and those between different CLS authors. Each of the six sections in this Part includes examples of both types; both support the thesis of this Note. Examples of the second type can be considered genuine "contradictions" because CLS is a bona fide movement: it attempts to offer a viable alternative to the liberal vision from a certain direction, and it embodies a relatively defined set of presuppositions and commitments. Moreover, the conflicting rhetorical arguments examined here do not deal with peripheral or fringe issues in CLS, but rather with central issues of the movement's methodology and vision. Finally, the contradictory rhetorical strains that this Note identifies are sufficiently pervasive in CLS scholarship that instances of each dichotomy can be found within the work of many or most CLS scholars. Thus, where this Note juxtaposes the writings of different scholars, it is simply to provide the clearest examples of particular thetorical inconsistencies.

30. Throughout this Note, the term "rhetoric" means the conventions of discourse and argument. See generally Wetlaufer, supra note 6, at 1546-48.

31. See generally Kennedy, supra note 1. 


\section{A. Inclusion and Exclusion}

The rhetoric of inclusion is a hallmark of CLS scholarship. CLS writers frequently adopt an unconventionally informal tone, accessible language, and imagery from popular culture. This rhetorical strategy reflects an implicit criticism of the exclusive, reified, and mystifying nature of conventional legal discourse.

Instead of the neutral, impersonal, reasoned propositions commonly found in law review articles, ${ }^{32}$ one finds in CLS work claims like this one: "Law professors are, in fact, a kiss away from panic at every serious, self-conscious moment in which they don't have a bunch of overawed students to kick around."33 CLS scholars use expressions like "It would be a bummer"34 and "You know."35 They also punctuate their writing with references to popular culture, including drama, ${ }^{36}$ film, ${ }^{37}$ baseball, ${ }^{38}$ music, ${ }^{39}$ and science fiction..$^{40}$ Popular music lyrics are commonly quoted in CLS literature. ${ }^{41}$ One scholar has included musical scores along with the words of rock songs in two of his articles-the first one on the indeterminacy of language ("De do do do, de da da da"), ${ }^{42}$ and the second on the freezing of power relationships by legal discourse ("The trouble with normal is it always gets worse."). ${ }^{43}$ Another inclusive device is the use of dialogue. Although it is seen elsewhere in legal scholarship, $^{44}$ the dialogue is an especially popular format for CLS work. ${ }^{45}$

\footnotetext{
32. See Wetlaufer, supra note 6 , at 1569-71.

33. Kelman, Trashing, 36 STAN, L. REV. 293, 322 (1984).

34. Kennedy, Cost-Reduction Theory as Legitimation, 90 YALE L.J. 1275, 1282 (1981).

35. Gabel, The Phenomenology of Rights-Consciousness and the Pact of the Withdrawn Selves, 62 TEx.
} L. REV. 1563, 1599 (1984).

36. See, e.g., Kennedy, Spring Break, 63 TEX. L. REV. 1377, 1385 (1985) ('In a way, edging towards Punta Rieles, we were just actors . . . . [W] we were also narrators and directors, creating our roles and casting as we wished in a production staged against the backdrop of Ana's imprisonment.").

37. See, e.g., Hutchinson, Indiana Dworkin and Law's Empire (Book Review), 96 YALE L.J. 637, 637 (1987). Hutchinson's radically innovative review of Dworkin's book Law's Empire is cast entirely in a film motif, complete with opening credits and critical acclaim.

38. See, e.g., Tushnet, The Dialectics of Legal History (Book Review), 57 TEX. L. REv. 1295, 1305 (1979) (comparing himself to Billy Martin and George Steinbrenner; comparing G. Edward White to Enos Slaughter, baseball player who recently failed to win election to Baseball Hall of Fame).

39. See, e.g., Gabel \& Kennedy, Roll Over Beethoven, 36 STAN. L. REV. 1,1 (1984) (quoting Chuck Berry song); Tushnet, Darkness on the Edge of Town: The Contributions of John Hart Ely to Constitutional Theory, 89 YALE L.J. 1037, 1037 (1980) (referring to Bruce Springsteen's Darkness on the Edge of Town).

40. See, e.g., Singer, supra note 13, at 47 (citing science fiction novels); Tushnet, An Essay on Rights, 62 TEX. L. REV. 1363, 1369 n.18 (1984) (same).

41. See, e.g., Gabel \& Kennedy, supra note 39, at 1 (quoting Chuck Berry's Roll Over Beethoven); Hutchinson \& Monahan, supra note 2, at 245 (quoting Van Morrison's Dweller on the Threshold).

42. Hutchinson, supra note 7, at 237-38 n.149 (quoting Police song).

43. Hutchinson, Part of an Essay on Power and Interpretation (With Suggestions on How to Make Bouillabaisse), 60 N.Y.U. L. REv. 850, 859-60, 886 n.225 (1985) (quoting Bruce Cockburn lyric).

44. The classic example is Hart, The Power of Congress to Limit the Jurisdiction of Federal Courts: An Exercise in Dialectic, 66 HARV. L. REV. 1362 (1953).

45. See, e.g., Fraser \& Freeman, What's Hockey Got to Do With It, Anyway? Comparative CanadianAmerican Perspectives on Constitutional Law and Rights, 36 BUFfalo L. REV. 259 (1987); Freeman \& Schlegel, Sex, Power and Silliness: An Essay on Ackerman's Reconstructing American Law, 6 CARDOZo L. REV. 847, 848 (1985); Gabel \& Kennedy, supra note 39; Hutchinson, supra note 43; Nelson \& Gordon, 
This form of inclusive rhetoric reflects a conscious strategic decision to "operate in the interspace of artifacts, gestures, speeches and rhetoric, histrionics, drama ... pop culture, all that kind of stuff." ${ }^{46}$

These devices combine to create a rhetoric of accessibility, inclusion, and egalitarianism. First, such thetoric refuses to accept the coercive structure of legal discourse: it insists that there is no legal order "out there" separate from ordinary social relations. ${ }^{47}$ Instead, it invites us to feel included in legal discourse, to realize that law is no less a contingent human creation-and should be no less accessible - than baseball or music. Second, the informality of the language and the casual references to everyday phenomena cast the reader in the role of the writer's close companion, in much the same way as the language used by Hemingway ${ }^{48}$ The dialogue form and other rhetorical gestures reflect an attempt to break down the hierarchical social relationships between writer and reader and between teacher and student. This parallels the substantive CLS preference for egalitarianism, participation, and "unalienated relatedness" 49 over hierarchy and exclusion. ${ }^{50}$

Yet, a conflicting rhetoric is also prominent in CLS, one that is decidedly inaccessible and exclusive. Consider the following passage:

Such a metastructuralist account of the relationship of structuralist and phenomenological discourses reduces their historic alternation to a movement within an intra- (meta-) structural time and dissolves the subjectivity of even subjectivist discourse. But the evident artificiality of this metastructural analysis could be subjected to a poststructuralist attack and itself interpreted as testament to my voluntaristic creation of a theory of contradictory grammars. ${ }^{51}$

Another CLS scholar has stated: "It is not inconsistent to, on the one hand, realize the projective temporal character of human existence, in which no one is identity, and the living subject is continually not what he or she is by moving

An Exchange on Critical Legal Studies Between William Nelson and Robert Gordon, 6 LAW \& HIST. REV. 139 (1988). As Drucilla Cornell has explained:

The very notion of dialogue entails a symmetric reciprocity between participants who treat each other not as adversaries to be defeated but rather as partners in a common conversational enterprise. This reciprocity allows for the construction of an ethic of citizenship that reclaims practical reason from the oblivion to which liberal culture has consigned it.

Cornell, Toward a Modern/Postmodern Reconstruction of Ethics, 133 U. PA. L. REV. 291, 298 (1985).

46. Gabel \& Kennedy, supra note 39 , at 9.

47. See Gordon, supra note 26 , at 197.

48. See W. ONG, INTERFACES OF THE WORD 62-64 (1977).

49. Gabel \& Kennedy, supra note 39 , at 1 . Running through nearly all CLS work is the desire to create "a more decent, equal, solidary society-less intensively ordered by hierarchies of class, status, 'merit,' race, and gender-more decentralized, democratic, and participatory." Gordon, supra note 26, at 197.

50. Art and popular music are seen as "means of transmitting shared understandings into feelings of connectedness, which form the basis of community." Jaff, Law and Lawyer in Pop Music: A Reason for Self-Reflection, 40 U. MIAMI L. REV. 659, 661 (1986).

51. Heller, supra note 15 , at $160-61$. 
- into the next moment in a creative and constitutive way ...."52 Such abstract, inaccessible language is typical of critical legal scholarship, ironically punctuated by Bruce Springsteen lyrics and informal colloquialisms. This dense new mode of argument seems to recreate with a vengeance the exclusion and pedagogical hierarchy implicitly criticized by CLS's inclusive rhetoric: if the reader is not a member of the club of "ethereal scholar[s]" 53 who have mastered Derrida, Saussure, and Habermas, ${ }^{54}$ she is likely to feel frustrated or mystified-not at all like the writer's close companion. Thus CLS scholarship has been charged with being "smarter-than-thou," "55 "impenetrable,"56 and aimed at "an exclusive audience of insiders." to be two contradictory rhetorical commitments: a rhetoric of inclusive egalitarianism and a rhetoric of exclusive hierarchy.

But it might be argued that such a characterization is unfair to CLS because the "exclusive" rhetoric is merely the imported language from social theories that are substantively inclusive, egalitarian, and demystifying; the contradiction, therefore, is only on the surface. There are two responses to this argument. First, an important CLS theme is that substance cannot be separated from form. ${ }^{58}$ It is therefore problematic for CLS to rely on some notion of substance wholly separate from rhetorical form. Indeed, it is precisely this sort of argument that CLS rejects in the context of legal discourse; it is the form-the rhetoric - of rules, rights, and legalisms within legal discourse that causes alienation and false consciousness, regardless of any "substantive" commitment to egalitarianism..$^{59}$ Second, this argument does not deny the existence of a contradiction between the two rhetorical commitments: the rhetoric of inclusion unmistakably criticizes lofty, inaccessible discourse; the rhetoric of exclusion incorporates just such discourse. The point here is not to criticize CLS's use of the rhetoric of continental theorists by itself; indeed, such language probably must be used in order to communicate a wide range of subtle and important ideas. Rather, the point is to show how CLS fails to meet its own tough standard of participatory openness. CLS writers use rhetoric to call for radical inclusion, but then end up using rhetoric only to discourse among themselves.

52. Gabel \& Kennedy, supra note 39, at 19 (Peter Gabel).

53. Delgado, The Ethereal Scholar: Does Critical Legal Studies Have What Minorities Want?, 22 HARV. C.R.-C.L. L. REV. 301, 301 (1987).

54. CLS draws substantially on the work of these and other continental theorists. See Balkin, Deconstructive Practice and Legal Theory, 96 YALE L.J. 743, 744-45; Hutchinson \& Monahan, supra note 2, at 215, 229.

55. Carlson, Contradiction and Critical Legal Studies (Book Review), 10 CARDOZo L. REv. 1833, 1834 (1989).

56. Id.

57. Matsuda, Looking to the Bottom: Critical Legal Studies and Reparations, 22 HARV. C.R.-C.L. L. REv. 323, 342 (1987).

58. See sources cited supra note 7.

59. See, e.g., Gordon, supra note 26, at 198; Tushnet, supra note 40, at 1363-71. 


\section{B. Subjectivism and Structuralism}

The use of informality and artifacts of popular culture in CLS scholarship is also closely connected to the CLS critique of formalism in legal discourse generally. In law, rigid, formal rules constrain the possibilities of creative change and create a false sense of objectivity. So too, the abstract, formal language of legal scholarship threatens to limit thought and create a false sense of mechanical or scientific neutrality ${ }^{60}$ To combat this, CLS scholars are irreverent, deliberately breaking the implicit rules of decorum in legal scholarship (if only to show that they can be broken): they decry the "mind-fucks of capitalism," 61 "encrustations of the shit-hierarchy,"62 "fucking oppression," 63 and "reified, ideological shit." ${ }^{64}$ This is the rhetoric of subjects-of radically autonomous individuals unconstrained by formal structures. A central aim of CLS is "to unfreeze the social structure of meaning, to free up the possibilities for new ways to think and act in the world." ${ }^{\circ 5}$ Indeed, some CLS scholars call themselves "irrationalists"66 and "nihilist[s]."67 They argue that there is no rational foundation or epistemology supporting moral and legal claims, ${ }^{68}$ and their rhetoric correspondingly substitutes informality and irreverence for the usual authoritative, impersonal, rational-sounding discourse of the law. This subjectivist rhetoric portrays the subject as primary-as free of all social and epistemological structures, which are inherently oppressive; the individual is the source of meaning and truth, and is capable of achieving radical change through intentional action.

Alongside this subjectivist rhetoric in CLS there is a strong structuralist rhetoric. ${ }^{69}$ The structuralist rhetoric rejects the primacy of the subject, and instead critiques the legal order by relying on an authoritative moral, epistemological, or social framework. One example of this is the angry and moralistic

60. See Hutchinson, supra note 7, at 237.

61. Kennedy, The Role of Law in Economic Thought: Essays on the Fetishes of Commodities, 34 AM. U.L. REV. 939, 969 (1985).

62. Kennedy, First Year Law Teaching as Political Action, J.L. \& Soc. PROBS. 47, 49 (1980).

63. Kelman, supra note 33, at 321.

64. Worden, Overshooting the Target: A Feminist Deconstruction of Legal Education, 34 AM. U.L. REV. 1141, 1152 (1985).

65. Peller, Debates About Theory Within Critical Legal Studies, 1 LzaRd 3-4 (1984) (copy on file with author).

66. Id.

67. This term was first used in Tushnet, Truth, Justice, and the American Way: An Interpretation of Public Law Scholarship in the Seventies, 57 TEX. L. REV. 1307, 1340 (1979).

68. See, e.g., Peller, supra note 65 , at 3-4; Singer, supra note 13 , at $4-5$ \& n.8.

69. Following James Boyle, this section uses the term "structuralist" broadly to refer to "a focus on clusters of beliefs, ideas, or economic forces that supposedly have their own internal logic and that somehow organize, explain, or are reflected in the subjective experiences of those who are affected by them." Structuralism aims at "uncovering 'what is really going on." Boyle, supra note 15 , at 742, 743. In this sense, structuralism includes versions of historicism and objectivism as well as the more technical sense of structuralism, which implies a commitment to the methods developed by such writers as Barthes, LeviStrauss, Lacan, Piaget, and Althusser. See id. at 742 n.165. Boyle identifies a "tension" between the subjectivist and structuralist strands within CLS. See id. at 736-78. 
rhetoric found running throughout much CLS writing. Duncan Kennedy declares that liberal ideas are "wrong and corrupt,"70 consisting of "lies and errors."71 Mark Tushnet refers to Laurence Tribe's work as "morally obtuse."72 The "moralistic consciousness"73 to which CLS appeals is too consistent and powerful to reflect merely a subjective view or preference; indeed, language like "consciousness" implies that there is a moral framework "out there," that we can be conscious of it, and that we can authoritatively use it to evaluate the central ideas of liberal theory. Similarly, the focus on the "deep structure" of liberal thought ${ }^{74}$ and "fundamental contradictions" embedded therein ${ }^{75}$ seems to imply an essentialist picture of liberalism and an objective epistemological framework. ${ }^{76}$ In fact, Kennedy claims that these contradictions form "the very essence of every [legal] problem."77

The CLS structuralist rhetoric can also be seen in its emphasis on social and historical forces and structures. Roberto Unger uses the language of progressive historical evolution reminiscent of Hegel. ${ }^{78}$ The deterministic economic structuralism of Marx also runs through much CLS literature. ${ }^{79}$ These accounts stress the role of structures in social life, and, to the extent that they have transhistorical explanatory power, they necessarily reject the primacy of the subject celebrated by the subjectivist rhetoric.

One can see these contradictory rhetorical commitments at work by examining how CLS depicts the political tilt of the legal system. CLS characterizes the legal system as nonneutral, ${ }^{80}$ ideological, and an "instrument of class domination."81 But the two conflicting rhetorics of subjectivism and structuralism locate the nonneutrality or tilt at different levels. In many places, CLS scholars focus on individual subjects. Law's tilt derives from the fact that it "infinitely manipulable," 82 that it is a matter of the decisionmaker's "personal

70. Kennedy, supra note 62 , at 57.

71. Kennedy, Critical Labor Law Theory: A Comment, 4 INDUS. REL. L.J. 503, 503 (1981).

72. Tushnet, Dia-Tribe (Book Review), 78 MICH. L. REV. 694, 710 (1980) (reviewing L. TRIBE, AMERICAN CONSTTIUTIONAL LAW (1978)).

73. Tushnet, supra note 2 , at 1528.

74. R. UNGER, KNOWLEDGE AND POLITICS 8 (1975).

75. Kennedy, supra note 17, at 211 (1979).

76. See Boyle, supra note 15 , at 713-15, 758.

77. Kennedy, supra note 17 , at 213 .

78. Unger writes:

By an irresistible movement, which imitates the attraction death exercises over life, thought again and again uses the instruments of its own freedom to bind itself in chains. ... [E]verything in the history of thought happens as if it were meant to remind us that, though death lasts forever, it is always the same, whereas life, which is fleeting, is always something higher than it was before.

R. UNGER, supra note 74, at 1; see also Kronman, Book Review, 61 MINN. L. REV. 167, 182 (1976) (arguing that Unger uses Hegelian methodology).

79. See Boyle, supra note 15 , at 721-30, 762-65; Hutchinson \& Monahan, supra note 2, at 221.

80. Singer, supra note 13 , at $40-45$.

81. Gordon, supra note 16 , at 94 .

82. Singer, supra note 13 , at 10. 
preference," 83 and that it "provides only a wide and conflicting variety of stylized rationalizations from which courts pick and choose." ${ }^{84}$ However, at other points, the law's tilt is portrayed as clearly systemic or structural: law is a collective "hallucination," 85 "an instrument of class domination." 86 According to this alternative "rhetoric of responsibility,"87 law is not a subterfuge for base motivation or prejudice; in fact judges and other legal actors generally do their best to follow what they (mistakenly) suppose the law requires. But the system as a whole perpetuates social and economic inequalities ${ }^{88}$ while legal rules serve as "the opiate of the masses." ${ }^{\prime 9}$ If the structure of the legal order really does contain the systemic tilt described by CLS, then legal actors have to be relatively constrained in making legal decisions in order to make the "system" operate in its definitively tilted way. But this constraint on legal actors is precisely what is denied by the "manipulation" and "choice" elements of the subjectivist thetoric.

More is at stake, however, than CLS's characterization of the source of the law's political tilt. In its subjectivist moments, CLS rejects the very possibility of foundations - of acontextual, transhistorical, and neutral claims about reality. But the language of opiates and hallucinations implies that there is an underlying natural social reality, which is simply obscured by the drug of the liberal order. The suspicion that CLS reintroduces foundational rationality into its own thought is confirmed by its structuralist rhetoric-its reliance on essences, objectivist (or at least transhistorical/transcultural) moralism, and inevitable social evolution. When CLS writers argue that the law is "mere artifact,"90 they intend the characterization as a critique-as if CLS has access to something that is not mere artifact. But as CLS's subjectivism teaches, there can be access to no such thing.

83. Kennedy, Freedom and Constraint in Adjudication: $A$ Critical Phenomenology, 36 J. LEGAL EDUC. 518,519 (1986).

84. Kairys, supra note 12, at 3 (emphasis added); see also M. TUSHNET, RED, WHITE, AND BLUE 19192 (1988) ("[T]he acceptable techniques of legal reasoning . . . allow us to assemble diverse precedents into whatever pattern we choose.").

85. Gabel \& Kennedy, supra note 39 , at 34, 40.

86. Gordon, supra note 16 , at 95 .

87. Balkin, supra note 6 , at 197 . Balkin shows how different ways of characterizing phenomena have the effect of allocating responsibility in importantly different ways. See generally id.

88. See, e.g., Gordon, supra note 16, at 93; Tushnet, Deviant Science in Constitutional Law, 59 TEX.

L. REV. 815, 817 (1981); Tushnet, supra note 38, at 1295.

89. M. KELMAN, supra note 2 , at 63.

90. Kennedy, Legal Education As Training for Hierarchy, in THE POLITICS OF LAW: A PROGRESSIVE CRITIQUE, supra note 12, at 47; see also S. FISH, Anti-Professionalism, in DOING WHAT COMES NATURALLY 215, 229 (1989) (arguing that Kennedy's language reveals belief in absolute reality). 


\section{Legal Indeterminacy and Critical Determinacy}

One finds CLS articles marked by bizarre language such as: "loopification,"91 "trashing,"92 "windbag rhetoricians,"93 "Yin-Yang Balance,"94 "mumbo-jumbo,"95 "jabber,"96 "intersubjective zap,"97 "mishmash,"98 and "yuk." These words mock the technical jargon of traditional legal discourse, placing it in absurd perspective. The parody in this rhetoric is closely tied to CLS arguments about legal indeterminacy. In particular, words like "mumbojumbo" and "mishmash" seem intended to denote undefinable nonsense; the point of carrying them into the domain of legal scholarship-which normally sounds like "the voice of reason itself" 100 -is to posit that the indeterminacy of such words is not so different from that of many words frequently bandied about in legal discourse, words like "fairness," "fault," and "duress." 101 The unbridled language that CLS writers embed into the text of legal scholarship acts out the poststructuralist discovery of the "free play of language."102 As the French critic Roland Barthes observed, the text becomes "that uninhibited person who shows his behind to the Political Father."103 This rhetoric of legal indeterminacy is related to the inclusive and subjectivist rhetorics discussed above: it criticizes the reification of elusive, indeterminate concepts and structures of meaning.

But once again, a conflicting rhetoric - that of critical determinacy-undermines the first. The previous two sections showed how abstract discussions of phenomenology and social theory in CLS make it susceptible to charges of inaccessibility and structuralism. ${ }^{104}$ In the same way, reliance on theories of "unalienated relatedness," 105 "counterhegemonic thought,"106 and "false consciousness"107 opens CLS to its own critique of radical indeterminacy. The ambiguous, elusive nature of such fundamental concepts in CLS's own political prescriptions is striking in light of the all-out CLS attack on the indeterminacy of liberalism's constructs. Indeed, CLS scholars appear committed to both con-

91. Kennedy, The Stages of the Decline of the Public/Private Distinction, 130 U. PA. L. REv. 1349, 1354 (1982).

92. Kelman, supra note 33, at 293.

93. Id. at 336.

94. Id. at 346.

95. Id.

96. Freeman \& Schlegel, supra note 45 , at 852 .

97. Gabel \& Kennedy, supra note 39 , at 4.

98. Id.

99. Id.

100. Wetlaufer, supra note 6 , at 1569 .

101. Singer, supra note 13 , at 18.

102. See T. EAGLETON, LTTERARY THEORY 138-41 (1983).

103. R. BARTHES, THE PLEASURE OF THE TEXT 53 (1973).

104. See supra notes 51-57, 78-79 and accompanying text.

105. Gabel \& Kennedy, supra note 39 , at 1.

106. M. KELMAN, supra note 2 , at 270.

107. Boyle, supra note 15 , at 767 n.252. 
demning and praising indeterminacy. On the one hand, the claim of indeterminacy is presented as a critique that threatens the very legitimacy of the legal system. ${ }^{108}$ Indeterminacy is viewed as allowing judges to manipulate legal doctrine to suit their ends in an exercise of illegitimate coercive power. ${ }^{109}$ On the other hand, CLS writers use rhetoric that seems to glorify the attributes of "plasticity"110 and the transformative possibilities of broad contextual standards over rigid, definite rules, ${ }^{111}$ thereby ultimately preserving indeterminacy as a value in their own vision.

These contradictory rhetorical commitments also play themselves out in another way. ${ }^{112}$ Two propositions that are central to CLS are that law is indeterminate and that law is politics. ${ }^{113}$ But if law is really both indeterminate and entirely reducible to politics, then it appears to follow that politics (or at least that subset of politics consisting of the "legal" sphere) is also indeterminate. But CLS certainly does not want to make this claim, because it would undermine CLS arguments about the determinative role of social and economic forces in history. ${ }^{114}$ Initially, therefore, it looks like the law-is-indeterminate claim is inconsistent with the law-is-politics claim, given what CLS means by the latter.

But CLS has a response to this apparent inconsistency. What CLS scholars mean by arguing that law is indeterminate is that law is internally indeterminate-that is, the legal rules and principles constituting the authoritative legal materials do not justify the outcomes of legal disputes; rather, the outcomes are determined by something external to those materials. ${ }^{115}$ This allows CLS to claim both that law is (internally) indeterminate and that law is a matter of politics. However, if this is the sense of "indeterminacy" as used by CLS, then the force of the critique turns on what is included in the definition of "legal materials." Joseph Singer, for example, writes somewhat derisively of "legal culture, conventions, 'common sense,' and politics ... rather than reason" as extralegal factors determining results. ${ }^{116}$ Many liberal scholars, however, have argued that context, conventions, and practical judgment are included within 14.

108. See Kennedy, Legal Formality, 2 J. LEGAL STUD. 351, 351-54 (1973); Singer, supra note 13, at

109. See Kennedy, supra note 108 , at 354.

110. Kennedy, supra note 83, at 562; Wetlaufer, supra note 6, at 1590; see also R. UNGER, FALSE NECESSITY: ANTI-NECESSITARIAN SOCIAL THEORY IN THE SERVICE OF RADICAL DEMOCRACY 484 (1987); Note, Plastics: Unger and Ackerman on Transformation, 98 YALE L.J. 1173 (1989).

111. See generally Kennedy, supra note 1.

112. What follows is a corollary to the observation made at the end of the preceding section. See supra text accompanying notes 80-90.

113. See Tushnet, supra note 2 , at 1518 .

114. See supra text accompanying notes 78-79.

115. See Singer, supra note 13 , at 9-25.

116. Id. at 25 . This leads one to wonder how these phenomena are different from the "broad standards" and "context" CLS favors. 
the category of legal materials. ${ }^{117}$ Once notions like these are admitted as tools in legal reasoning, the degree of internal indeterminacy in the law becomes substantially less, and the claim that law is politics becomes obvious, but not so damning. Ironically, the CLS rhetoric of indeterminacy presumes a quite narrow, formalistic conception of legal rationality. Having assailed formalism, CLS turns around and implicitly demands a degree of formalism in the law that has been widely discredited for decades. ${ }^{118}$

\section{Humanism and Transcendentalism}

Religious imagery plays a significant role in critical legal scholarship. A good example is Mark Kelman's depiction of the sense of awe inspired by law professors, creating the feeling that one is "in the presence of keepers of great secrets or priests with access to privileged thought." 119 But he quickly debunks this mystical feeling by pointing out that it would not exist "if the students were told explicitly that people just need a little practice before they can engage in a subculture's discourse." 120 CLS ridicules "rights priest[s]"121 and "phony priests"122 who preach that, by performing the proper rituals and invoking the necessary incantations, the legal order will work wonders, such as protecting rights and dispensing justice.

This rhetoric reveals a contempt for the transcendent and religious. It attempts to expose the mystical appeal of legal discourse to the light of day, and to replace it with humanism. The CLS critique of rights utilizes a similar humanistic rhetoric. Rights, like religion, are viewed as transcendent phenomena that mystify us and cement the existing social order. ${ }^{123}$ They protect only ephemeral things, such as speech and religious worship, but never guarantee human needs and tangible values like economic justice. ${ }^{124}$

117. See, e.g., S. BURTON, AN INTRODUCTION TO LAW AND LEGAL REASONING 176-214 (1985); R. DWORKIN, LAW'S EMPIRE 13-15 (1986); Kress, Legal Indeterminacy, 77 CALIF. L. REV. 283, 320-31; Stick, Can Nihilism Be Pragmatic?, 100 HARV. L. REV. 332, 345-52 (1986). The recent surge of interest in legal pragmatism similarly reflects an expanded conception of legal reasoning which emphasizes contextual and pragmatic considerations. See, e.g., Symposium on the Renaissance of Pragmatism in American Legal Thought, 63 S. CAL. L. REV. 1569 (1990).

118. Ken Kress has persuasively detailed the various ways in which critical legal scholars are "cdisappointed absolutist[s]." Kress, supra note 117, at 320-35 (quoting H.L.A. HART, THE CONCEPT OF LAW 135 (1961)). For two recent attempts to revive formalism from its current state of disrepute, see Schauer, Formalism, 97 YALE L.J. 509 (1988); Weinrib, Legal Formalism: On the Immanent Rationality of Law, 97 YALE L.J. 949 (1988). Even these accounts, however, are moderate in comparison to the narrow conception of legal rationality set up by CLS to establish its claims of indeterminacy.

119. Kelman, supra note 33 , at 325.

120. Id. at 326.

121. Gabel \& Kennedy, supra note 39 , at 40.

122. M. KELMAN, supra note 2 , at 1 .

123. See Freeman, Antidiscrimination Law: A Critical Review, in THE POLITICS OF LAW: A PROGRESSIVE CRITIQUE, supra note 12, at 96; Gabel, supra note 35.

124. See, e.g., Kennedy, supra note 90 , at $48-49$. 
Yet CLS is often itself considered a religion of sorts, ${ }^{125}$ and the strong moralistic rhetoric discussed earlier ${ }^{126}$ contains religious fervor and overtones. Nowhere is the transcendent and religious thetoric stronger than in the work of Roberto Unger. His utopian, communitarian vision is self-consciously and unambiguously Christian. ${ }^{127}$ Rather than displaying the usual critical irreverence, Unger describes a shift from the emptiness of the "old religion" to a deep reverence for something higher-a new religion: "When we came, they were like a priesthood that had lost their faith and kept their jobs. They stood in tedious embarrassment before cold altars. But we turned away from those altars, and found the mind's opportunity in the heart's revenge." 128 The mocking tone of other CLS writing contrasts sharply with Unger's heartfelt prayer at the end of Knowledge and Politics: "Speak, God." 29

Unger's mystical, upward-looking rhetoric is precisely the opposite of the humanistic, grassroots appeal seen in CLS writers' use of artifacts from popular culture and irreverence. Unger's obscure utopian vision requires a leap of faith, ${ }^{130}$ while other CLS scholars call for skepticism toward lofty and elusive constructs; Unger envisions a "superliberalism,"131 while other CLS scholars strive to get the abstract theorists within their movement "down off their high horses." 132 The two opposing rhetorical commitments represent a fundamental dichotomy in the CLS project between specific, concrete proposals for change, ${ }^{133}$ and utopian, transcendent visions of social consciousness. ${ }^{134}$ In the end, however, both commitments appear to be undermined by CLS's own critique. As a radical movement, CLS firmly rejects incremental reform; ${ }^{135}$ its own concrete reform proposals must therefore fall victim to the charge that they falsely legitimate liberalism. On the other hand, the CLS critique of indeterminacy and mystification threatens to undermine its own reliance on notions like "unalienated relatedness" and "community": concepts such as these, along with transcendent appeals to a utopian future, can easily be seen as just as indeterminate and mystifying as the constructs of liberal discourse.

125. See, e.g., Schwartz, With Gun and Camera Through Darkest CLS-Land, 36 STAN. L. REV. 413, 416 (1984).

126. See supra text accompanying notes $24,70-73$.

127. See R. UNGER, PASSION: AN ESSAY ON PERSONALITY 22-29 (1984); Powell, The Gospel According to Roberto: A Theological Polemic, 1988 DUKE L.J. 1013, 1013.

128. Unger, The Critical Legal Studies Movement, 96 HARV. L. REV. 563, 675 (1983).

129. R. UNGER, supra note 74, at 295. Unger has been called "the Christ figure" of CLS. Schwartz, supra note 125 , at 416.

130. Boyle, supra note 15 , at 760 .

131. Unger, supra note 128 , at 602 .

132. Gabel \& Kennedy, supra note 39, at 5.

133. See Kelman, supra note 33 , at 302 (documenting specific CLS reform proposals).

134. See, e.g., R. UNGER, supra note 74. See generally Gabel \& Kennedy, supra note 39 (discussing tension within CLS).

135. See Hutchinson \& Monahan, supra note 2, at 244. 
James Boyle has identified a parallel dichotomy within CLS between "local" critique and "large-scale" or global critique. ${ }^{136}$ The premise of local critique (advocated by Boyle and widely privileged in CLS) is that "our social theory should not be based on the analysis of large-scale ideologies," 137 but rather on local spheres of life and discourse. But there is a remarkable tendency in CLS discourse to make the grandest of ideological claims, and Unger's work provides a good example of this tendency. The striking thing about this is that even those CLS scholars who condemn such global critiques through their rhetoric fall into the trap. Boyle, for example, recognizes that Unger's theory seems "perverted by its urge for totalization"; ${ }^{138}$ yet a page later he changes his mind, concluding: "It is a total theory within a fairly narrow locality, narrow because its excellence lies in the way it takes apart the formalized structure behind liberal political discourse, and liberal political discourse is narrow." 139 The problem, of course, is that Boyle's new use of the term "local" would allow everything to count as local with a little creative rhetorical characterization, and thus the distinction loses all its force.

\section{E. Particularity and Abstraction}

David Kennedy's article, Spring Break, ${ }^{140}$ is one of the most rhetorically innovative articles in legal scholarship. Written in 1985, the article is simply a forty-page narrative of Kennedy's trip to Uruguayan prisons. The narrative contains no footnotes and no talk of rights or of comparative legal systems, but only of people, concrete events, and feelings. The reader is led to wonder if this is really legal scholarship; Kennedy's implicit question is, Why is it not legal scholarship? He calls attention to our complex, structured presuppositions about legal thinking in an attempt to demystify and delegitimate. His rhetoric is a radical celebration of what he calls the " $p$ 's in legal life: the personal, private, particular, and passionate."141 The article certainly forms a part of the inclusive, subjectivist, and humanist rhetorics described previously. But its special contribution is to a rhetoric of particularity: it purports to present a unique event in an elegant meditation, stripped of all theoretical trappings.

And yet, Spring Break takes a strikingly ironic turn. Following the narrative, Kennedy includes a brief but dense, heavily footnoted appendix "situating Spring Break in contemporary legal scholarship." 142 The appendix is techni$\mathrm{cal}$, abstract, and didactic, using terms of art from modern continental theorists and including phrases like "repudiating the attempt to predetermine the inde-

136. Boyle, supra note 15 , at $773-76$.

137. Id. at 773-74.

138. Id. at 774 .

139. Id. at 775 .

140. Kennedy, Spring Break, 63 TEX. L. REV. 1377 (1985).

141. Id. at 1421 .

142. Id. at 1417. 
terminacy of claims" and "decentering my own textual presence." 143 A further irony is that CLS scholars, who constantly cite and rely on each other's work, ${ }^{144}$ appear to have cited Spring Break only once-in a footnote criticizing David Kennedy's scholarship as "simply academic - a congealed and reified by-product of a forgotten political moment."145 In fact, while the article has been cited by non-CLS scholars, ${ }^{146}$ the only specific page-references to the article's content are to the abstract appendix, not the innovative narrative. ${ }^{147}$ It appears, then, that CLS itself has had difficulty incorporating this type of rhetorical innovation into a practicable form of legal scholarship. Instead one finds an almost inevitable lapse back into traditional didactic form, or worse, elusive abstraction. While the narrative form of rhetoric has begun to thrive among other scholars, particularly minority and feminist scholars, ${ }^{148}$ Spring Break stands as a failed attempt at radical incorporation of the "particular" and "personal" into critical legal scholarship.

\section{F. Radical and Mainstream}

CLS has been both the subject and the source of battle imagery. ${ }^{149}$ Tushnet has said, "[W]hen they find out what we're doing, they're going to come after us with guns." 150 The popular press has appropriated this rhetoric, depicting CLS as "guerrilla warfare." 151 The radical rhetoric of CLS reflects its fundamental ambition: "Revolution, not reform." 152 Kelman writes, "We will lead silly lives if we ever stop raging against the usual. We must always be ready to strike."153 At the 1984 convention of the American Association of Law Schools, for example, CLS members distributed an "alternative" newspaper which conjures up radical images in both style and content. Called

143. Id. at 1422 .

144. Schwartz, supra note 125 , at 440 .

145. Freeman, Racism, Rights and the Quest for Equality of Opportunity: A Critical Legal Essay, 23 HARV. C.R.-C.L. L. REV. 295, 321 (1988).

146. See Frankenberg, Down By Law: Irony, Seriousness, and Reason, 83 Nw. U.L. REV. 360,390 $\mathrm{n} .80$ (1989); Linzer, The Decline of Assent: At-Will Employment as a Case Study of the Breakdown of Private Law Theory, 20 GA. L. Rev. 323, 426 n.490 (1986); Schlag, Missing Pieces: A Cognitive Approach to Law, 67 TEX. L. REV. 1195, 1217 n.87 (1989).

147. See Caudill, Disclosing Tilt: A Partial Defense of Critical Legal Studies and a Comparative Introduction to the Philosophy of the Law-Idea, 72 IOWA L. REV. 287, 356 (1987); Minda, The Jurisprudential Movements of the 1980 s, 50 OHIO ST. L.J. 599, $620 \mathrm{nn} .100$ \& 103 (1989).

148. See, e.g., Legal Storytelling, 87 MrCH. L. REV. 2073 (1989) (symposium including works by Derrick Bell, Richard Delgado, Mari Matsuda, and Patricia Williams).

149. See Bratton, Manners, Metaprinciples, Metapolitics and Kennedy's Form and Substance, 6 CARDOZO L. REV. 871, 871 n.1 (1985).

150. Schlegel, Notes Toward an Intimate, Opinionated, and Affectionate History of the Conference on Critical Legal Studies, 36 STAN. L. REV. 391, 403 (1984) (quoting Tushnet).

151. Menand, Radicalism for Yuppies, NEw REPUBLIC, March 17, 1986, at 20; see also Margolick, The Split at Harvard Goes Down to Its Foundations, N.Y. Times, Oct. 6, 1985, § 4, at 7, col. 1 .

152. Hutchinson \& Monahan, supra note 2, at 244.

153. Kelman, supra note 33 , at 348. 
Lizard, ${ }^{154}$ it is a collage of polemics, articles, pop-style cartoons, fragments of old drawings, and advertising slogans. The format was popularized by French revolutionary student movements during the 1960's and remains a symbol of left-wing "underground" movements. ${ }^{155}$ Lizard has been quoted and referred to by scholars both within and outside the movement. ${ }^{156}$

Another classic example of the CLS brand of radical form is Duncan Kennedy's book, Legal Education and the Reproduction of Hierarchy. ${ }^{157}$ The book is designed as a "little red book." It is not listed in Books in Print, and its publisher, the Afar Press, is not in the Boston telephone directory. ${ }^{158}$ The preface ends with the call: "Resist!" 159

It is evident that CLS, and Duncan Kennedy in particular, intentionally foster the form and rhetoric of radicalism. The conflicting mainstream rhetoric in CLS, while not intentionally fostered, is nevertheless equally evident. A perfect example of the conflict is provided by a comparison of Kennedy's "little red book" to his article, Freedom and Constraint in Adjudication: A Critical Phenomenology. ${ }^{160}$ In this article, Kennedy imagines himself as a federal judge in Boston deciding a case. The conflict between Kennedy pretending to be, on the one hand, a revolutionary publishing underground books, and on the other hand, a federal judge, is a perfect model of the divided rhetorical tendencies within CLS. The fact is that most CLS scholars are, in an important sense, privileged insiders who rely on their positions at prestigious institutions, ${ }^{161}$ and are not "indifferent to considerations of hierarchy." 162 It should perhaps not be surprising, therefore, to find Kennedy's radical rhetoric somewhat contrived: he probably could not publish a book with the Afar Press and expect people to read it were he not a Harvard law professor who has been published in renowned law journals. Kennedy's Freedom and Constraint article, by contrast, is remarkable for its tameness. In the article, we see that as (Judge) Kennedy goes through his reasoning process, he actually is constrained to a significant degree by the law, even though the case he chooses to examine is a difficult labor law case touching on many conflicting legal rules and doctrines. Moreover, his arguments and rhetoric seem surprisingly mainstream.

The conflicting radical and mainstream rhetorics may result in part from the rather strange position in which CLS scholars find themselves: near the top

154. 1 LIZARD (1984) (copy on file with author).

155. Luban, Legal Modernism, 84 MICH. L. REV. 1656, 1676-77 (1986).

156. See, e.g., id. at 1677; Hutchinson, supra note 37, at 657; Johnson, supra note 2, at 286-87 n.103.

157. D. KENNEDY, LEGAL EDUCATION AND THE REPRODUCTION OF HIERARCHY (1983).

158. Wise, Of Lizards, Intersubjective Zap, and Trashing: Critical Legal Studies and the Librarian, 8 LEGAL REF. SERVICES Q. 7, 13 (1988).

159. D. KENNEDY, supra note 157 , at ii.

160. Kennedy, supra note 83.

161. See Delgado, supra note 53, at 320.

162. Tushnet, supra note 2 , at 1541 n.99. 
of social hierarchies that they perceive as fundamentally illegitimate. ${ }^{163}$ Their positions in those hierarchies privilege them to speak with authority and give them the audience they seek, so that they can effectively criticize and strive to break down the very hierarchies they inhabit.

\section{CONCLUSION: CONTRADICTION AND THE CLS VISION}

The rhetorics examined in the previous Part were primarily those that stand out - those that are stylistically radical or unconventional in the forum of legal scholarship. It is important to realize, however, that a great deal of CLS scholarship is basically traditional in its rhetorical form. While there is a distinctive rhetoric in traditional legal scholarship, ${ }^{164}$ that rhetoric "operates through the systematic denial that it is rhetoric."165 Therefore, there is a final dichotomy at work in CLS: that between the privileging of form and the privileging of substance, between rhetoric and philosophy. ${ }^{166}$ CLS's use of nontraditional rhetoric - its privileging of the personal, the metaphorical, and the radical-appears to have been steadily declining in the last five years. ${ }^{167}$ Original rhetorical innovators such as Kelman, Kennedy, and Tushnet have moved toward more traditional rhetoric. ${ }^{168}$ Contradiction in CLS's rhetorical commitments inheres even in its meta-rhetoric.

The contradictory rhetorical commitments examined in this Note reveal that CLS's personality is fundamentally split. At bottom, each contradiction can be understood as connected to the "fundamental contradiction" between freedom and security identified by Duncan Kennedy. ${ }^{169}$ The rhetorics of inclusion, sub-

163. The most obvious of these hierarchies is the legal education hierarchy. Many CLS scholars are in positions of power (as professors) at places of power (elite law schools such as Stanford and Harvard) within a profession of power (law). It is only fair to point out, however, that CLS scholars have also been generally marginalized within the legal academy, and several have been denied tenure in law schools. See Tushnet, supra note 2, at 1519 n.18, 1530-34 (discussing tenure denials); see also Carrington, Of Law and the River, 34 J. LEGAL EDUC. 222, 227 (1984) (asserting CLS scholars have "ethical duty to depart the law school"). The less obvious, but arguably more interesting hierarchies that privilege most CLS scholars are those of class, race, and sex. See Matsuda, supra note 57, at 342.

164. This is the thesis of Wetlaufer, supra note 6 . That traditional rhetoric is objective, neutral, impersonal, and certain. Id. at 1568.

165. Id. at 1555.

166. For a discussion of the ancient quarrel between philosophy and rhetoric, see S. FISH, Rhetoric, in DoINg What Comes NaTURAlly 471 (1989).

167. Compare Gabel \& Kennedy, Roll Over Beethoven, 36 STAN. L. REv. 1 (1984) (informal dialogue) and Kelman, Trashing, 36 STAN. L. REV. 293 (1984) (irreverent, informal style) with M. KELMAN, A GUDE TO CRITCAL LEGAL STUDIES (1987) (technical, impersonal writing) and Kennedy, The Effect of the Warranty of Habitability on Low Income Housing: "Milking" and Class Violence, 15 FLA. ST. U.L. REV. 485, 495 (1987) (technical, didactic style, including economic analysis).

168. At least some CLS scholars are quite conscious of this shift. Tushnet has recently written: Some of the radical edge is gone from both the rhetoric and the intellectual positions of the people who identify themselves with cls. I should note (or confess) that I have detected some blurring of the edges in my own work. Although I would like to think this results from maturation and reflection, I am not sure that it does; it may just be a sort of Sartrean bad faith on my part.

Tushnet, supra note 2, at 1522 n.30.

169. Kennedy, supra note 17 , at 211-12. 
jectivism, indeterminacy, humanism, particularity, and radicalism derive from the human desire for freedom; the rhetorics of exclusion, structuralism, determinacy, transcendentalism, abstraction, and the mainstream derive from the desire for security.

At some level, CLS recognizes that there are tensions and inconsistencies in its scholarship. But CLS scholars also claim to have completely "trashed" liberal theory by revealing deep contradictions within it. They suppose that the CLS vision of the world either transcends or mediates those contradictions. At the very least, therefore, this Note's analysis of the contradictory commitments in CLS suggests that similar fundamental contradictions are not avoided, but are embedded in critical legal thought.

Critical legal scholars believe that there is a core to liberalism, that within liberal discourse there is a dominant set of presuppositions and commitments. ${ }^{170} \mathrm{CLS}$ attempts to offer a viable alternative to the liberal vision; it too embodies a relatively defined set of presuppositions and commitments. Its rhetoric reveals these commitments. In fact, CLS scholarship itself contains an ostensible or privileged rhetorical commitment. On the surface, critical legal scholars self-consciously and consistently celebrate the rhetoric of "freedom," as embodied in the first member of each oppositional pair considered here: inclusion, subjectivism, indeterminacy, particularity, humanism, and radicalism. And yet, this thetoric inevitably gives way to that of "security," as embodied in CLS's rhetorical commitments to exclusion, structuralism, determinacy, abstraction, transcendentalism, and the mainstream. These contradictory rhetorical commitments inhere within the work of particular CLS scholars, and also throughout the movement as a whole. Moreover, there has been a gradual shift over time toward a heightened reliance on the rhetoric of security and a corresponding deemphasis of the rhetoric of freedom.

This analysis thus reveals something deeper about Critical Legal Studies. While it claims to be a radical, utopian movement, CLS ultimately fails to offer a consistent radical vision. One CLS scholar, having identified fundamental tension within critical legal thought, has declared: "[W]e should not be dispirited because what we need is makeshift work surfaces, not Platonic tables." 171 Yet this is simply a version of the most common liberal response to the CLS critique. ${ }^{172}$ What, then, fundamentally distinguishes critical legal theory from liberal theory? Makeshift work surfaces should be left to the liberals. If anyone has the luxury of being internally consistent and philosophically pure, it is a visionary radical movement. Otherwise the requisite "leap of faith" is not really a leap, and demands no faith.

170. See, e.g., M. KELMAN, supra note 2, at 4, 15-85; R. UNGER, supra note 74, at 3 (describing liberalism as "a single mode of thought [of which the] premises . . . are few").

171. Boyle, supra note 15 , at 778 .

172. See, e.g., A. Altman, Critical Legal Studies: A Liberal CrTIQUE $145-47$ (1990) (arguing law does not require perfect determinacy and clear foundations); Kress, supra note 117, at 320-36 (same). 